\title{
RESPON KARDIOVASKULER AKIBAT LATIHAN
}

Oleh: Widiyanto

Dosen Jurusan Pendidikan Kesehatan dan Rekreasi FIK UNY

\section{Abstrak}

Kaitan olahraga dengan jantung dan pembuluh darah dapat dipahami karena dengan jantung merupakan organ vital yang memasok kebutuhan darah di seluruh tubuh. Dengan meningkatnya aktivitas fisik seseorang maka kebutuhan darah yang mengandung oksigen akan semakin besar.

Latihan fisik yang dilakukan sesuai dengan prinsip-prinsip dasar latihan fisik akan memberikan pengaruh yang baik terhadap tubuh, yaitu terjadinya peningkatan kualitas fisik.adapun perubahanperubahan yang dimaksud, perubahan kardiorespirasi yang meliputi ; perubahan cardiac out-put, perubahan stroke volume, perubahan denyut jantung (denyut nadi) dan perubahan tekanan darah.

Kata Kunci: Olahraga, Kardiorespirasi

Olahraga atau latihan fisik tidak hanya melibatkan sistem muskuloskeletal tetapi juga sistem kardiovaskuler, respirasi, ekskresi, dan saraf. Latihan harus mempunyai takaran yang tepat baik intensitas, lama maupun frekuensinya untuk mencapai hasil maksimal dalam meningkatkan daya tahan, kecepatan reaksi, kemampuan pengambilan oksigen, kekuatan otot termasuk otot jantung dalam mengontrol 
tekanan darah dan denyut nadi. Latihan dibagi menjadi latihan aerobik dan anaerobic. Olahraga kini sudah menjadi kebutuhan'masyarakat secara luas. Terbukti dari bertumbuhnya pusat-pusat olahraga serta dipenuhinya ruang-ruang publik pada hari libur oleh masyarakat yang berolahraga. Hal ini menunjukkan bahwa olahraga bukan hanya sekedar kebutuhan, namun sudah menjadi gaya hidup. Pada umumnya mereka melakukan olahraga untuk menjaga kebugaran tubuh serta menjaga kesehatan, akan tetapi tidak sedikit juga mereka yang melakukannya karena hobi atau mengejar prestasi.

Rasulullah saw. bersabda, "Mukmin yang kuat lebih baik dan lebih disukai Allah daripada mukmin yang lemah" (HR Muslim). Hadits ini memperlihatkan bahwa selain mementingkan kekuatan iman, Islam juga peduli terhadap kekuatan jasmani umatnya karena dari kekuatan jasmani itulah ibadah dapat ditegakkan. Dalam hadits lain,Nabi Muhammad saw. bersabda, "Segala sesuatu di luar zikir kepada Allah Swt. Adalah permainan atau senda gurau, kecuali empat hal: perjalanan seseorang diantara dua tujuan, melatih kuda, mencumbu istri, dan belajar berenang" (HR alBazzar dan al-Thabrani). Dalam hadits ini, beliau 
menganjurkan kita untuk belajar berenang, salah satu olahraga yang sangat bermanfaat.

Pada perkembangannya, banyak masyarakat melakukan olahraga yang bertujuan untuk memelihara dan meningkatkan kesehatan. Olahraga semacam ini dapat kita sebut sebagai olahraga kesehatan. Olahraga kesehatan memiliki sifat mudah dikerjakan, murah, serta bermanfaat dan aman. Untuk itu, olahraga kesehatan memiliki beberapa syarat yang harus dipenuhi agar tercapai tujuannya, yaitu intensitas serta bebannya homogen, submaximal, serta tidak boleh ada unsur kompetisi didalamnya. Yang dimaksud sebagai beban homogen disini adalah intensitas serta porsi dari laihan selalu sama. Olahraga yang baik adalah olahraga yang secara intensitas dilakukan secara teratur dan berkesinambungan. Sedangkan yang dimaksud sebagai submaximal disini adalah tidak ada pemaksaan yang melebihi kemampuan individu tersebut baik dalam beban maupun intensitasnya. Selain terfokus pada kesehatan jasmani, olahraga untuk kesehatan ini juga berpengaruh positif pada kesehatan rohani serta sosial individu tersebut karena selain mudah dan murah, olahraga ini dapat dilakukan secara massal. 
Canadian Society for Exercise Physiology (1998) dalam "physical activity guide" menyebutkan bahwa untuk menjaga tubuh tetap sehat diperlukan aktifitas fisik seperti berjalan kaki selama 60 menit per hari. Sedangkan untuk aktifitas fisik yang lebih berat,seperti bersepeda atau berenang diperlukan waktu 30-60 menit 4 kali seminggu. Apabila seseorang melakukan olahraga aerobic atau jogging maka diperlukan waktu 20-30 menit. Namun,aktifitas ini harus dilakukan secara bertahap dan teratur untuk mencapai hasil yang optimal.

Manfaat melakukan olahraga yang cukup dan teratur telah diinformasikan secara luas dalam berbagai artikel kesehatan maupun artikel populer serta jurnal-jurnal kesehatan. Diantara manfaat itu antara lain, olahraga dapat mencegah obesitas, diabetes mellitus, hyperlipidemia, stroke, dan hipertensi. Bahkan Veronique dan Robert (2005) dalam penelitiannya di belgia menyimpulkan bahwa latihan aerobic dapat diterapkan sebagai manajemen hipertensi bukan hanya untuk pencegahan. Masih dalam penelitian yang sama disebutkan juga bahwa lemak dalam darah dapat diturunkan kadarnya dengan olahraga terutama aerobik. Lemak dalam darah inilah yang nanti akan menimbulkan arterosklerosis apabila kadarnya tinggi. Sebuah studi di jepang (Akira et

MEDIKORA Vol. IV, No 1, April 2008: 24-46 
al,1983) menyimpulkan bahwa latihan aerobik yang dilakukan pada 50\% VO2max efektif terhadap terapi hipertensi ringan.

Kaitan olahraga dengan jantung dan pembuluh darah dapat dipahami karena dengan jantung merupakan organ vital yang memasok kebutuhan darah di seluruh tubuh. Dengan meningkatnya aktivitas fisik seseorang maka kebutuhan darah yang mengandung oksigen akan semakin besar. Kebutuhan ini akan dipenuhi oleh jantung dengan meningkatkan aliran darahnya. Hal ini juga direspon pembuluh darah dengan melebarkan diameter pembuluh darah (vasodilatasi) sehingga akan berdampak pada tekanan darah individu tersebut.

\section{LATIHAN}

Definisi latihan olahraga yang dimodifikasi Dietrich Herre (1971) menyatakan bahwa latihan adalah suatu proses penyempurnaan olahraga yang diatur dengan prinsip-prinsip yang bersifat ilmiah, khususnya prinsip-prinsip paedagogis. Proses ini direncanakan dan sistematis, yang meningkatkan kesiapan untuk melakukan dan kapasitas penampilan atlet. Menurut Dietrich Martin yang dikutip M. Furqon, 1995: 3, latihan olahraga adalah suatu proses yang direncanakan yang 
mengembangkan penampilan olahraga yang komplek dengan memakai isi latihan, tindakan-tindakan organisasi yang sesuai dengàn maksud dan tujuan. Latihan adalah suatu proses berlatih secara sistematis yang dilakukan secara berulang-ulang dengan beban latihan yang kian bertambah (Harsono, 1996: 17). Hal senada juga dikemukakan oleh Mosston (1992: 9) bahwa latihan merupakan pelaksanaan gerakan secara berurutan dan berulang-ulang. Pada prinsipnya latihan adalah memberikan tekanan fisik secara teratur, sistematik, berkesinambungan sedemikian rupa sehingga dapat meningkatkan kemampuan fisik di dalam melakukan aktivitas (Fox dkk, 1993: 69).

Pendapat lain mengenai pengertian latihan adalah proses sistematis dari kerja fisik yang dilakukan secara berulang-ulang dengan menambah jumlah beban pekerjanya. Latihan fisik merupakan pemberian atau beban fisik pada tubuh secara teratur, sistematis, dan berkesinambungan melalui program latihan yang tepat (Astrand dan Rodahl, 1986:11).

Latihan fisik sebaiknya dilakukan sesuai dengan kemampuan tubuh dalam menganggapi stress yang diberikan, bila tubuh diberi beban latihan yang terlalu ringan maka tidak akan terjadi proses adaptasi (Sugiharto, 2003: 4).

MEDIKORA Vol. IV, No 1, April 2008: 24-46 
Demikian juga jika diberikan beban latihan yang terlalu berat dan tubuh tidak mampu mentolelir, akan menyebabkan terganggunya proses homeostatis pada sisitem tubuh dan dapat mengakibatkan kerusakan pada jaringan. Setiap latihan fisik atau laihan akan menimbulkan respon atau tanggapan dari organ-organ tubuh terhadap dosis/beban latihan yang diberikan, hal ini merupakan usaha penyesuaian diri dalam rangka menjaga keseimbangan lingkungan yang stabil atau bisa disebut juga dengan homeostatis (Sugiharto, $2003: 7)$.

Latihan merupakan salah satu stressor fisik yang dapat menggangggu keseimbangan homeostatis. Oleh sebab itu, pemanfaatan latihan yang dikemas dalam bentuk latihan fisik memerlukan pengukuran dosis yang tepat, sehingga memberikan peluang untuk membentuk mekanisme penyakit (coping) yang mampu mengubah stressor menjadi stimulator. Tetapi bila dosis latihan yang diberikan tidak tepat, maka stressor tersebut akan mengganggu keseimbangan (homeostatis) dalam tubuh dan dapat menyebabkan masalah kelainan biologis/patologis (Sugiharto, $2003: 1$ ).

Semua aktivitas fisik merupakan stressor bagi tubuh. Jika tubuh diberi stressor yang dilakukan secara teratur, berkesinambungan, dan disertai dengan program latihan yang 
tepat, maka tubuh akan beradaptasi dengan membentuk mekanisme coping yang mampu mengubah stressor menjadi stimulator. Pemberian beban latihan akan ditanggapi oleh tubuh dalam bentuk respon, jika dosis yang diberikan tepat akan menghasilkan proses adaptasi yang baik. Program/dosis latihan yang tepat haruslah memperhatikan beberapa unsur latihan, yaitu: frekuensi, intensitas, durasi, dan set latihan.

\section{TEKANAN DARAH}

\section{Definisi Tekanan Darah}

Tekanan darah dapat diartikan sebagai tekanan yang diberikan oleh darah pada dinding dalam pembuluh darah. Guyton (1996) mengartikan tekanan darah sebagai kekuatan yang dihasilkan darah terhadap setiap satuan luas dinding pembuluh darah. Walaupun pengertian tekanan darah ini berlaku pada seluruh sistem vaskuler, namun yang sering kita sebut sebagai tekanan darah merupakan tekanan darah arteri yang merupakan cabang dari aorta.

Pengukuran tekanan darah arteri selama siklus jantung dapat diukur secara langsung dengan menghubungkan alat pengukur tekanan ke sebuah jarum yang dimasukkan ke dalam arteri. Namun pengukuran dapat dilakukan secara lebih nyaman dan akurat, yaitu secara tidak langsung dengan

MEDIKORA Vol. IV, No 1, April 2008: 24-46 
menggunakan sphygmomanometer, suatu manset yang dapat dikembungkan dan dipakai secara eksternal lalu dihubungkan dengan pengukur tekanan. Apabila manset dilingkarkan mengelilingi lengan atas dan kemudian dikembungkan dengan udara, tekanan manset disalurkan melalui jaringan ke arteri brachialis di bawahnya, yaitu pembuluh utama yang mengangkut darah ke lengan bawah. Selama pengukuran tekanan darah, sebuah stetoskop diletakkan di atas arteri brachialis di lipat siku tepat di bawah manset. Bunyi tidak terdengar apabila tidak ada darah yang mengalir atau jika darah mengair secara normal, sedangkan aliran darah yang turbulen akan menimbulkan getaran yang dapat didengar. Pada permulaan pengukuran, manset dikembungkan hingga melebihi tekanan sistolik sehingga arteri kolaps. Karena tekanan manset yang besar maka arteri akan terjepit sehingga darah tidak akan mengalir pada arteri tersebut maka tidak terdengar bunyi. Ketika tekanan manset secara perlahan diturunkan dan berada tepat di bawah tekanan sistolik puncak maka arteri akan terbuka sedikit dan akan menyebabkan darah mengalir secara turbulen sehingga dapat didengar melalui stetoskop sebagai bunyi. Bunyi yang pertama kali terdengar inilah yang menandakan tekanan darah sistolik. Sewaktu tekanan manset terus turun, darah 
secara intermiten akan mengalir kembali secara turbulen setiap tekanan arteri melebihi tekanan manset. Sewaktu tekanan manset pertama kali berada di bawah tekanan arteri, maka arteri brachialis tidak terjepit lagi sehingga darah dengan leluasa akan melewati arteri ini. Karena aliran darah tidak lagi turbulen maka bunyi tidak akan terdengar. Maka tekanan tertinggi manset pada saat bunyi terakhir inilah yang kemudian kita sebut sebagai tekanan darah diastolik. (Sherwood,1996).

Pada praktek klinis, tekanan darah seseorang selalu dinyatakan dalam dua ukuran,misal 120/80. ukuran awal disebut sebagai tekanan sistolik sedangkan ukuran yang terakhir disebut sebagi tekanan diastolik. Tekanan sistolik merupakan tekanan arteri yang diperoleh pada saat jantung sedang melakukan kontraksi maksimal. Pada saat jantung mengalami relaksasi, tekanan arteri turun sampai ke titik terendah dan pada saat inilah tekanan diastolik dapat diukur. Tekanan darah dapat diukur dengan menggunakan alat yang disebut sebagai sphygmomanometer. Arteri yang memiliki denyutan paling besar dan terletak superficial antara lain arteri temporalis, carotis, facialis, brachialis, radialis, femoralis, poplitea, tibialis posterior dan dorsalis pedis (shier,2007). Namun dalam prakteknya, arteri yang lazim 
digunakan adalah arteri brachialis yang terletak di fossa cubiti.

\section{Regulasi Tekanan Darah}

Tekanan darah arteri rata-rata adalah gaya utama yang mendorong darah dari jantung menuju ke jaringan. Tekanan ini harus diatur secara ketat melalui regulasi yang kompleks karena dua alasan. Alasan pertama, tekanan ini harus cukup tinggi agar dapat menghasilkan tekanan yang cukup untuk mendorong darah menuju ke jaringan perifer. Kedua, tekanan darah tidak boleh terlalu tinggi yang akan mengakibatkan beban kerja jantung bertambah serta meningkatkan resiko rusaknya pembuluh darah dan rupturnya pembuluhpembuluh perifer yang halus. (sherwood,1996).

Tekanan arteri tidak diatur oleh satu sistem pengatur saja, tetapi oleh beberapa sistem yang saling berhubungan. Secara garis besar sistem-sistem ini terbagi menjadi dua sistem utama yaitu, (1) sistem mekanisme pengatur tekanan arteri yang bekerja secara cepat, dan (2) sistem pengatur tekanan arteri untuk jangka panjang. (Guyton,1996)

\section{PENGARUH LATIHAN PADA JANTUNG}

Latihan fisik yang dilakukan sesuai dengan prinsipprinsip dasar latihan fisik akan memberikan pengaruh yang 
baik terhadap tubuh, yaitu terjadinya peningkatan kualitas fisik.adapun perubahan-perubahan yang dimaksud, menurut Fox (1993) terdiri dari : perubahan kardiorespirasi yang meliputi ; perubahan cardiac out-put, perubahan stroke volume, perubahan denyut jantung (denyut nadi) dan perubahan tekanan darah.

\section{Perubahan cardiac out-put.}

Fox (1993), definisi cardiac out-put adalah sejumlah darah yang keluar per menit dari jantung, khususnya dari vertikel kiri. Kelihatan sedikit perbedaan cardiac out-put antara orang terlatih dan tidak, dengan rata-rata nilai diantara 5 sampai 6 liter/menit. Maksimal cardiak out-put pada laki-laki yang terlatih bisa mencapai nilai lebih 30 liter / menit. Ini menggambarkan 5 sampai 6 kali lebih meningkat pada keadaan istirahat. 


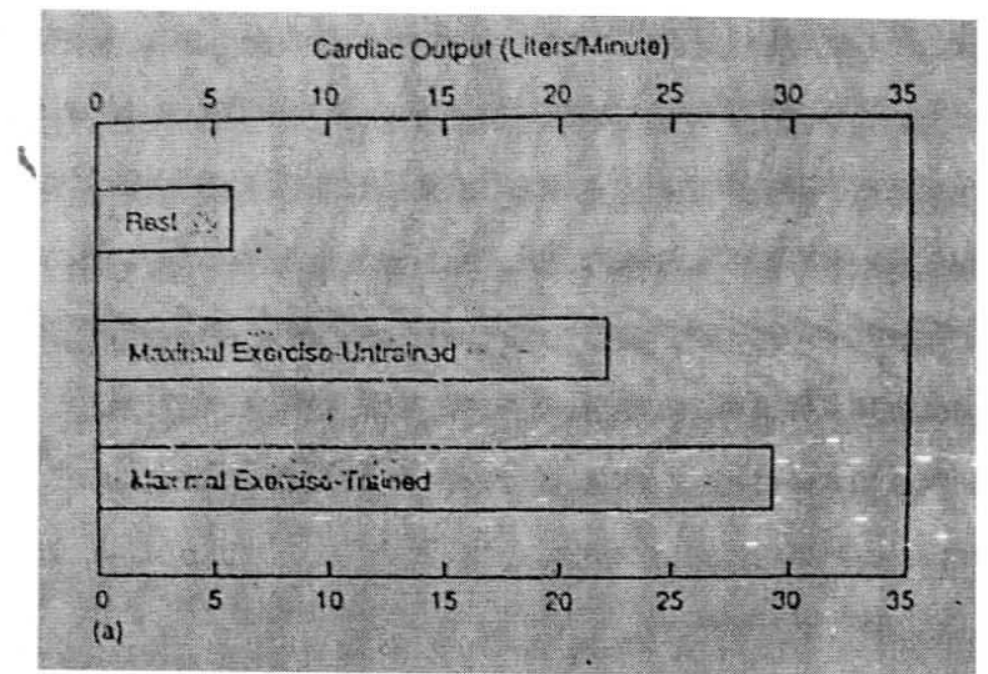

Gambar. Perubahan cardiac out-put pada waktu istirahat, latihan sub maksimal dan maksimal (Brooks, 1984).

\section{Perubahan Stroke Volume (Volume sekuncup)}

Menurut Fox (1993) stroke volume adalah sejumlah darah yang dipompa jantung per denyut. Stroke volume meningkat dengan cepat dari istirahat sampai latihan sub maksimal, tetapi tidak ada peningkatan dari latihan sub maksimal ke latihan maksimal.Stroke volume menjadi maksimal pada beban sub maksimal jika $\mathrm{VO}_{2}$ hanya sekitar $40 \%$ dari maksimum. Ini berlaku untuk orang yang terlatih dan tidak terlatih baik laki - laki maupun perempuan.

Stroke volume dipengaruhi oleh kekuatan kontraksi otot jantung terutama ventrikel, hal ini sesuai dengan hukum Frank starling. Hukum ini menyatakan bertambah banyak 
pengisian jantung selama diastole mengakibatkan lebih banyak pula darah yang dipompa ke dalam aorta, dengan kata lain dalam batas-batas fisiologis jantung aka memompakan semua darah yang masuk kedalam ventrikel tanpa menimbulkan penumpukan di vena (Fox,1993 ;Guyton,1996).

Pada saat istirahat, stroke volume pada laki-laki yang tidak terlatih rata-rata di antara 70-90 ml/denyut dengan nilai maksimal besarnya diantara 100-120 ml/denyut, Untuk laki-laki yang terlatih pada waktu istirahat maksimal nilai tertinggi rata-rata sekitar 100-120 ml dan 150-170 $\mathrm{ml} /$ denyut, sedangkan untuk atlet daya tahan laki-laki yang berlatih keras dinyatakan mencapai atau melebihi 200 ml/denyut (Fox, 1993).

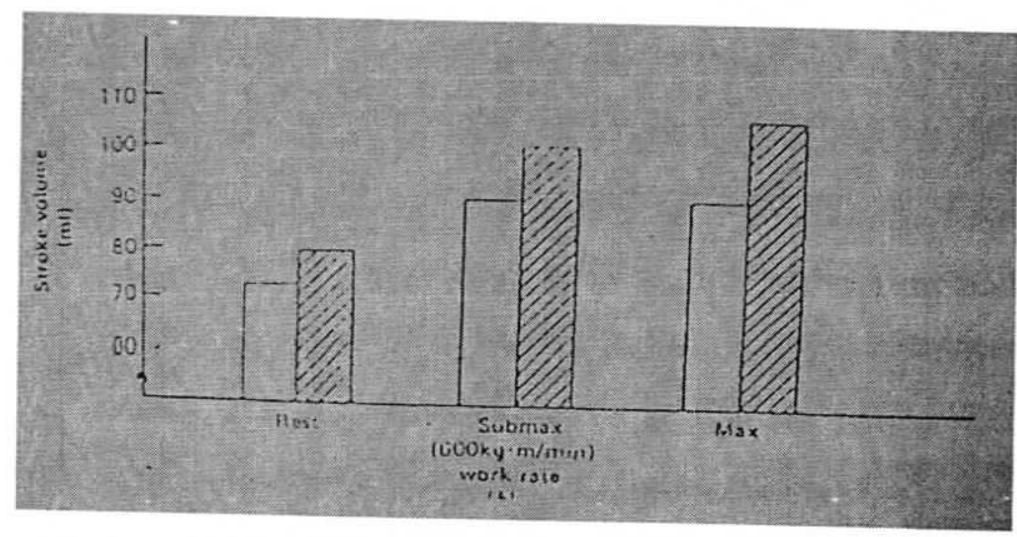

Gambar . Perubahan stroke volume pada saat istirahat, latihan sub maksimal dan maksimal (Brooks, 1984).

MEDIKORA Vol. IV, No 1, April 2008: 24-46 
Bila kita perhatikan gambar di atas bahwa volume sekuncup atau stroke volume pada saat istirahat lebih besar pada atlit dibandingkan yang bukan atlit, hal ini disebabkan oleh volume ventrikel pada atlit lebih besar. Kontraksi otot jantung meningkat mungkin disebabkan oleh peningkatan aktivitas enzim ATP-Ase dalan otot jantung atau perubahan konsentrasi ion kalsium pada cairan ekstrasel yang mempengaruhi elemen kontraktil jantung. Pada dasarnya nilai stroke volume wanita lebih rendah dari laki-laki dalam berbagai kondisi (Fox, 1993).

\section{Denyut jantung}

Denyut jantung berasal dari kontraksi otot jantung dimulai oleh peristiwa listrik (action potensial) ke peristiwa mekanik, yang berasal dari jaringan khusus S.A Node (Cardiac Cunduction System) dan menjalar melalui cardiac conduction system ini keseluruh bagian myocardium. Struktur sistem tersebut adalah Sino atrial Node (S A Node) yang disebut juga dengan pace maker, Atrioventricular Node (A V Node) (Guyton,1996).

Menurut Astrand (1986) mengatakan bahwa denyut jantung adalah debaran suara jantung yang menjalar sampai keujung pembuluh darah arteri yang ditentukan oleh tahanan dan tekanan darah. Pengaturan denyut jantung dan 
kekuatannya diatur oleh syaraf simpatis dan syaraf parasimpatis, syaraf simpatis berfungsi untuk menambah kecepatan dân kekuatan kontraksi otot jantung. Sedangkan syaraf parasimpatis berfungsi untuk memperlambat kontraksi otot jantung. Apabila cepat, kuat atau lambat kontraksi oto jantung, akan mempengaruhi kadar darah yang diedarkan ke seluruh jaringan tubuh (Fox, 1993).

Denyut jantung ini dibedakan menjadi dua antara lain : 1. Denyut jantung istirahat.

Seseorang secara fisiologis dikatakan sehat apabila suatu keadaan efisiensi fungsional yang optimal, suatu komponen yang dapat memberikan petunjuk tentang hal tersebut adalah frekwensi denyut jantung yang merupakan manifestasi dari kontraksi otot jantung. Brooks (1984) mengatakan, denyut yang baik dalam keadaan istirahat bisa berdenyut lebih lambat, sehingga menyebebkan lebih panjangnya waktu diastole jantung, sehingga jantung memompakan darah lebih banyak. Lebih lanjut Fox (1993) menambahkan arti dari frekwensi denyut jantung istirahat rendah, jantung dapat mengawetkan energi sekurangkururangnya 1500 denyutan per hari.

MEDIKORA Vol. IV, No 1, April 2008: 24-46 
2. Denyut jantung maksimal.

Frekwensi denyut nadi maksimal merupakan denyut nadi maksimal pada waktu melakukan kerja maksimal. Bompa (1994) mengatakan, bahwa maksimum heart rate diartikan sebagai denyut nadi maksimum yang dicapai dalam penampilan atau performanya. Untuk lebih jelasnya dapat dilihat pada gambar di bawah ini :

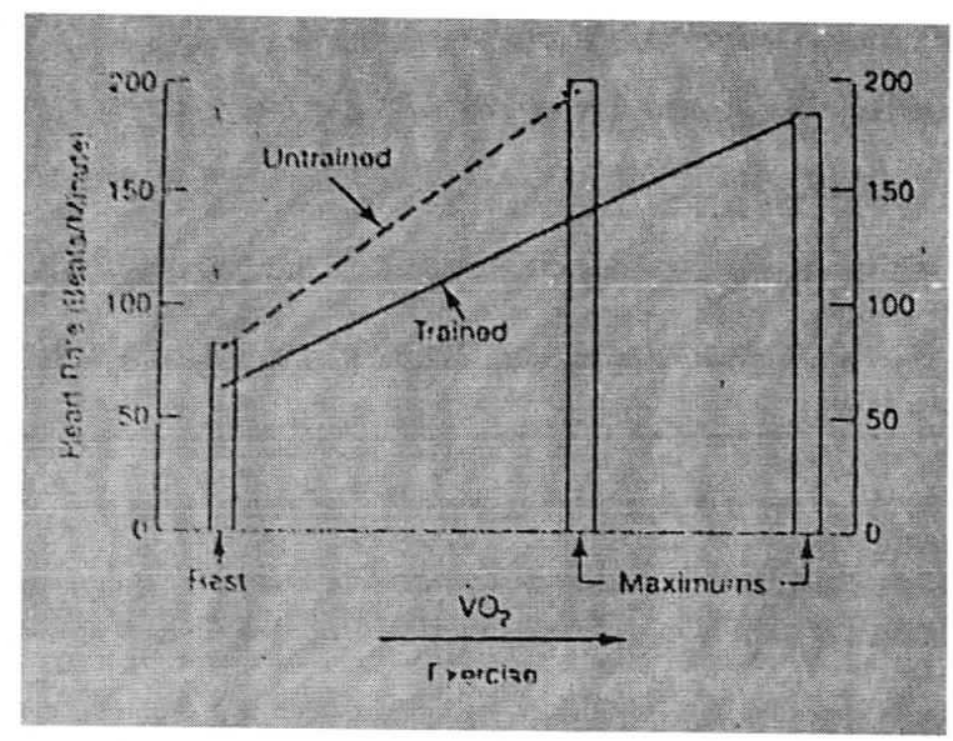

Gambar . Perubahan heart rate pada orang tidak terlatih dan terlatih (Brooks, 1984).

\section{Tekanan Darah}

Tekanan darah adalah kekuatan yang dihasilkan aliran darah terhadap setiap satuan luas dari dinding pembuluh (Guyton,1996).sedang kan Fox (1993) mengatakan tekanan 
darah adalah darah yang mengalir dari tekanan tinggi ke tekanan yang rendah. Darah yang mengalir dari ventrikel kiri dalam jantung ke aorta (terutama arteri pada sirkulasi sistemik), karena tekanan kontraksi ventrikel lebih kuat dibandingkan dalam aorta. Ada dua macam tekanan darah menurut Fox (1993): tekanan darah yang tinggi disebut tekanan sistole dan rendah disebut diastole.

Tekanan darah meningkat selama latihan, karena darah mengalir mungkin untuk mempertahankan daerah yang penting seperti jantung dan otak, tekanan darah sistole meningkat dan cardiac out-put meningkat (Brooks, 1984). Selanjutnya Strouss (1997) menambahkan, selama latihan dinamis yang meliputi kelompok otot skelet yang besar, dimana besarnya tergantung pada pemasukan oksigen pada peningkatan kebutuhan metabolisme kontraksi otot. Tipe aktivitas dalam meningkatkan cardiac out-put yang tinggi, heart rate dan stroke volume, secara relatif perubahan sedikit dalam rata-rata tekanan arteri. Tekanan sistole meningkat, tetapi tekanan diastole tidak berubah.

MEDIKORA Vol. IV, No 1, April 2008: 24-46 


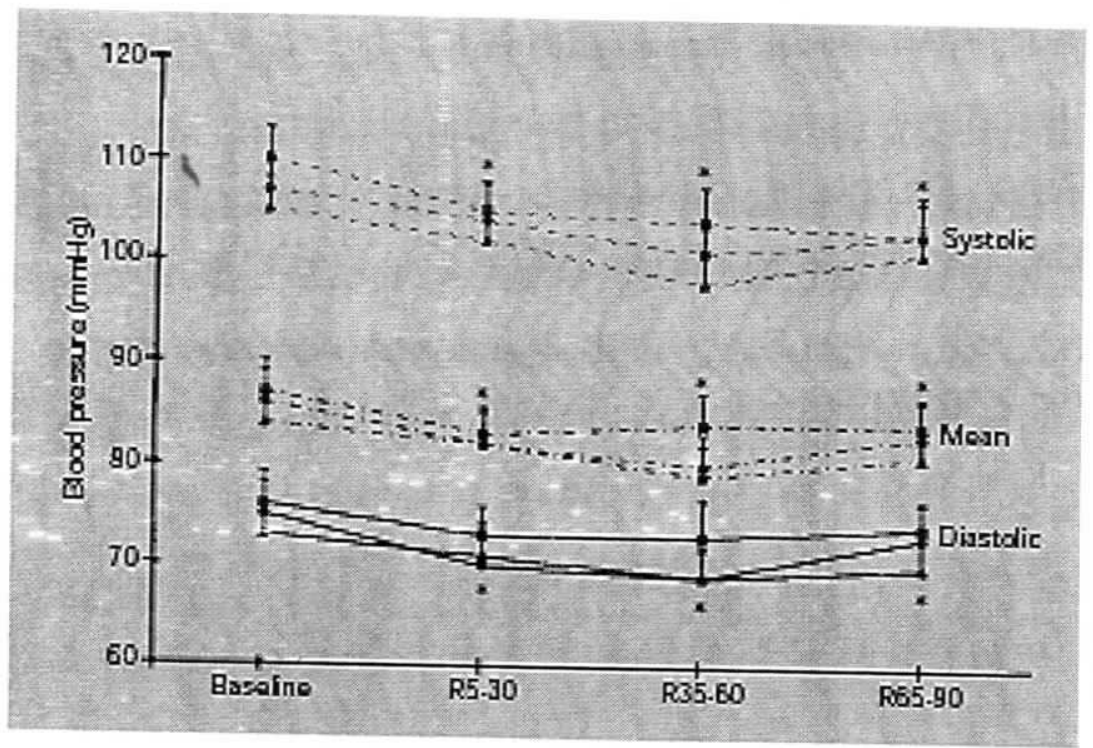

Gambar Perubahan tekanan darah setelah latihan (Forjaz: 1998)

\section{PENGARUH LATIHAN PADA RESPIRASI}

Respirasi ini juga sangat penting bagi kehidupan manusia selain yang tersebut diatas, karena pada respirasi ini pertukaran gas $\mathrm{O}_{2}$ dan $\mathrm{CO}_{2}$ sangat berperan dalam kehidupan sehari-hari dan kegiatan apapun. Pada taraf kerja tertentu diperlukan sejumlah oksigen. Makin tinggi taraf kerja, makin banyak jumlah energi yang diperlukan,jumlah oksigen yang diperlukan semakin banyak pula. Untuk meningkatkan fungsi respirasi, jalan yang terbaik adalah melakukan aktivitas olahraga dalam meningkatkan vitalitas 
fungsi paru, karena olahraga merangsang pernapasan yang dalam dan menyebabkan paru berkembang, dimana oksigen banyak masúk dan disalurkan ke dalam darah, karbohidrat lebih banyak dikeluarkan. Itu akan terlihat pada orang yang terlatih dan tidak terlatih dengan melakukan berbagai aktivitas tanpa rasa letih.

Menurut Fox (1993) perubahan cardio respirasi adalah hasil dari latihan terutama pada fungsi sirkulasi, dan perubahan terjadi pada :

1. Ventilasi maksimum semenit meningkat setelah latihan, tidal volume dan frekwensi pernapasan meningkat .

2. Efisiensi ventilasi meningkat, maka kebutuhan oksigen akan lebih rendah dari pada orang yang tidak terlatih, karena efisiensi ventilasi lebih baik akan menghasilkan sedikit oksigen pada respirasi-respirasi otot dan kerja otot skelet akan lebih banyak.

3. Dari hasil pengukuran paru pada saat istirahat (kecuali tidal volume) lebih besar pada orang terlatih daripada orang yang tak terlatih. Pada umumnya perubahan digambarkan dengan terjadinya perbaikan fungsi dan besarnya volume paru.

MEDIKORA Vol. IV, No 1, April 2008: 24-46 
4. Pada atlit terlatih cenderung mempunyai kapasitas diffusi lebih besar pada waktu istirahat dan selama latihan daripada non atlit, dan atlit pada cabang olahraga yang bersifat daya tahan/endurance mempunyai volume paru lebih besar dan aliran kapiler alveoler lebih baik.

Jadi dengan melakukan aktivitas aerobik terusmenerus dalam frekwensi latihan 3-5 hari per minggu, intensitas latihan antara 60-90\% dari maksimum denyut jantung, atau 50-85\% $\mathrm{VO}_{2}$ max dengan lama latihan 20-60 menit akan dapat memelihara kesegaran jasmani cardiovascular, komposisi tubuh serta kekuatan dan daya tahan bagi orang dewasa sehat (American college of Sport Medicine, 1990).

\section{KESIMPULAN}

Latihan fisik yang dilakukan sesuai dengan prinsipprinsip dasar latihan fisik akan memberikan pengaruh yang baik terhadap tubuh, yaitu terjadinya peningkatan kualitas fisik.adapun perubahan-perubahan yang dimaksud, terdiri dari : perubahan kardiorespirasi yang meliputi ; perubahan cardiac out-put, perubahan stroke volume, perubahan denyut jantung (denyut nadi) dan perubahan tekanan darah. 


\section{Daftar Pustaka}

Ananto, Purnomo \& Abdul Kadir. (1994). Memelihara Kesehatan dan Kebugaran Jasmani. Jakarta: Departemen Pendidikan dan Kebudayaan, Pusat Kesegaran Jasmani dan Rekreasi.

Astrand P.O. \& Rodahl. K. (1986). Text Book of Work Physiology, second edition. Mc. Graw Hill Company.

Astrand, P.O., Rodahl.K., Dahl, H.A., Stromme,S.B., 2003. Textbook of Work Physiology. Physiology Bases Of Exercise (4th ed. New Cork : McGraw-Hill.

Bompa, Tudor O. (1990). Theory ang Methodology of Training. Toronto Canada: Kendall/Hunt Publishing Company p29-44.

Brook GA, Fahey DF,1984, Fundamental of Human Performance, New York: Mcmillan,pp $280-292$.

Djojosugito, Ahmad. M., 1981. Segi Kedokteran Imu Faal Olahraga. Simposium Forum Dan Panel Forum Kesehatan Olahraga. Yogyakarta.

Forjaz, Matsudaita (1998). Post exercise changer in blood pressure heart rate and rate pressure product at different exercise intensities in normotensive hormone. Brazilian journals of medical and biological research. Brazil.

Fox. L Edward. (1993). The Physiological Basis for exercise and Sport. Madison, Wisconsin: Brown and Benchmark Publishers.

MEDIKORA Vol. IV, No 1, April 2008: 24-46 
Furqon, M. (1995). Teori Umum Latihan. Surakarta: ¿Universitas Sebelas Maret Press.

Giam, C.K., 1993 Imu Kedokteran Olahraga, Salma, 1994. (citase). Bina Rupa Aksara, Jakarta.

Guyton, C.A., Hall, E.J., 1996 Buku AjarFisiologi Kedokteran, Penerbit Buku Kedokteran EGC, Jakarta.

Harsono. (1996). Manusia dan Latihan. Bandung: ITB.

Kusmana, D., 2002. Olahraga Bagi Kesehatan Jantung, Fakultas Kedokteran Universitas Indonesia, Jakarta.

Moston, Muska. (1992). Teaching Physical Education. Ohio: Charles E. Meribt Publishing Company.

Powers SK, Howley ET, 2007. Exercise Physiology : Theory and Application to fitness and Perfomance, sixth Edition. USA: Mc. Graw Hill Company.

Shier, D., Butler, J., Lewis, Ricki., 2002. Hole's Human Anatomy \& physiology, 10th edition, Mc Graw Hill, New York .

Soekarman, 1987. Dasar-dasar Olah raga Untuk Pembina, Pelatih, dan attel, Cetakan Pertama. Jakarta: Inti Idayu Press, pp 60.

Sugiharto (2003). Adaptasi Fisiologis Tubuh Terhadap Dosis Latihan Fisik. Makalah disajikan dalam pelatihan senam aerobik, Laboratorium Ilmu Keolahragaan, Universitas Negeri Malang. 